\title{
Muhasebe Ĕ̈̆itimi Alan Üniversite Ö̆̆rencilerinin TMS/TFRS Hakkındaki İlgi Düzeyi, Beklenti ve Farkındalıklarına İlişkin Bir Araştırma: Giresun Üniversitesi İşletme Bölümü Örneği
}

\author{
A Research On Undergraduate Accounting Students' Interest Level, Expectation And \\ Awareness Of TAS/TFRS: The Case Of Giresun University Business Administration \\ Department
}

\author{
Alper KARAVARDAR* \\ Gizem KAYMAK**
}

$\ddot{O} Z$

\begin{abstract}
Araştırmada Giresun Üniversitesi İktisadi ve İdari Bilimler Fakültesi İşletme Bölümü ögrencilerinin TMS/TFRS hakkındaki ilgi düzeyi, beklenti ve farkındalıklarının ortaya konulması amaçlanmıştır. Araştırma sonucunda öğrencilerin cinsiyetleri ve ögretim programları ile TMS/TFRS ilgi düzeyi arasında anlamlı farklılı bulunmazken muhasebe ilgi düzeyleri, muhasebe meslek seçimi, TMS/TFRS dersini alma durumlarl ve TMS/TFRS ile ilgili derslerin bölümde zorunlu olarak verilmesini istemeleri ile TMS/TFRS ilgi düzeyi arası anlamlı farklılıklar olduğu tespit edilmiştir. Ayrıca öğrencilerin muhasebe ilgi düzeyi, muhasebe meslek seçimi, TMS/TFRS ile ilgili ders alma durumu ve dersin bölümde zorunlu olarak verilmesini istemeleri ile TMS/TFRS farkındalık düzeyi arasında anlamlı farklılık olduğu belirlenmiştir. Ögrencilerin beklentileri incelendiğinde ise çoğunluğun TMS/TFRS üzerine ayrı bir ders almadiğ ve bu dersin zorunlu ders olarak verilmesini istediği söylenebilir.
\end{abstract}

\section{ANAHTAR KELIMELER}

Muhasebe Standartlarl, Türkiye Muhasebe Standartlarl, Türkiye Finansal Raporlama Standartları

\begin{abstract}
The aim of the study was to determine the students' interest level, expectations and awareness about Turkish Accounting Standards/Turkish Financial Reporting Standards in Giresun University Faculty of Economics and Administrative Sciences As a result of the research, there was no significant difference between the gender and education programs and the TAS / TFRS interest level, while the level of accounting interest, choice of occupation, taking courses related to TAS ITFRS and requesting the TAS / TFRS courses to be compulsory in the department and TAS / TFRS interest level There were significant differences between. In addition, it is determined that there is a significant difference between TAS / TFRS awareness level and students' taking courses related to accounting interest level, accounting profession selection, TMS I TFRS and requesting the course to be compulsory in the department. When the expectations of the students were examined, it was concluded that the majority did not take a separate course on TAS / TFRS and that this course would be given as a compulsory course.
\end{abstract}

\section{KEYWORDS}

According Standards ,Turkish Accounting Standards, Turkish Financial Reporting Standards

\begin{tabular}{|c|c|c|}
\hline \multicolumn{2}{|r|}{$\begin{array}{c}\text { Makale Geliş Tarihi / Submission Date } \\
\text { 07.10.2019 }\end{array}$} & $\begin{array}{c}\text { Makale Kabul Tarihi / Date of Acceptance } \\
\text { 20.03.2020 }\end{array}$ \\
\hline Attf & $\begin{array}{l}\text { Karavardar, A. ve Kaymak, G. (2020). } \\
\text { Düzeyi, Beklenti ve Farkındalıklarına } \\
\text { Üniversitesi Sosyal Bilimler Meslek Yi }\end{array}$ & $\begin{array}{l}\text { Üniversite Öğrencilerinin TMS/TFRS Hakkındaki İlgi } \\
\text { Giresun Üniversitesi İşletme Bölümü Örneği. Selçuk } \\
\text { 1), 112-130. }\end{array}$ \\
\hline
\end{tabular}

\footnotetext{
* Doçent, Giresun Üniversitesi, İktisadi ve İdari Bilimler Fakültesi, İșletme Bölümü, akaravardar@yahoo.com, ORCID: 0000-0001-7330-4038

**Bilim Uzmanı, Giresun Üniversitesi, Sosyal Bilimler Enstitüsü, İşletme Bölümü, gzmkaymak@gmail.com,ORCID: 0000-0002-5605-2809
} 


\section{GİRIŞ}

Küreselleşme sürecinin etkisiyle ulusal sınırlar ortadan kalmış ve uluslararası çapta faaliyet gösteren şirketlerin sayısı artmıştır. Uluslararası ticaretin gelişmesiyle birlikte işletmeler hem kendi ülkelerinde geçerli muhasebe uygulamalarına hem de faaliyet gösterdiği diğer ülkelerde geçerli muhasebe uygulamalarına göre ayrı finansal tablolar hazırlamak zorunda kalmıştır (Turhan ve Oğuz, 2016: 882). Ülkelerarası finansal raporlama uygulamalarındaki farklılıklar uluslararası çapta genel kabul görmüş muhasebe standartlarının oluşturulması ihtiyacını ortaya çıkarmıştır.

Ülkelerin muhasebe alanında kendilerine özgü uygulamaları ve uluslararası firmaların yatırım yaptığı ülkelerde farklı mevzuatlar ile karşılaşması muhasebe alanında ortak bir dil oluşturmanın önemini ortaya koyarken küreselleşme sürecinin de etkisi ile uluslararası çapta şeffaf, anlaşılır ve karşılaştırılabilir finansal tablolar oluşturmak için muhasebe uygulamalarında standartlaşma yoluna gidilmiştir. Uluslararası genel kabul görmüş muhasebe standartlarının oluşumu ile finansal bilgi kullanıcılarının ihtiyaçlarını karşılayacak güvenilir, karşılaştırılabilir ve gerçeğe uygun bilgilerin üretilmesi amaçlanmıştır (Kocamaz, 2012: 106).

Literatürde muhasebe kavramı, "Bir örgütün kaynaklarının oluşumunu, bu kaynakların kullanılma biçimini, örgütün işlemleri sonucunda bu kaynaklarda meydana gelen artış veya azalışları ve örgütün finnansal açıdan durumunu açıklayan bilgileri üreten ve bunları ilgili kişi ve kuruluşlara ileten bir bilgi sistemi" olarak tanımlanmaktadır (Sevilengül, 2009: 3). Tanımdan da anlaşılacağı üzere bu bilgi sisteminin amaçlarından biri de işletmenin finansal durumunu yansıtacak şekilde finansal bilgi kullanıcılarının ihtiyaç duyduğu finansal bilgileri sağlamaktır (Yılmaz, 2007: 140). Muhasebe bilgi sisteminden elde edilen bilgilerin finansal bilgi kullanıcılarının ihtiyacına cevap vermesi, üretilen bilgilerin belirli standartlara göre hazırlanması ve mali tablolar aracılığıyla kullanıcılara sunulması ile mümkün olmaktadır (Üstündă̆, 2000: 31). Yatırımcılar, yöneticiler, mali kuruluşlar işletmelerin sunduğu tablolardan yola çıkarak çeşitli finansal kararlar almaktadır. İşletmelerin finansal durumunun incelenmesi, analizi ve karşılaştırılması açısından belirli ilke ve kuralların olması muhasebe alanında standartlaşmayı sağlamak adına önemlidir (Erdoğan ve Dinç, 2009: 155). Bu kapsamda Uluslararası Muhasebe Standartları Kurulu (IASB), küresel anlamda muhasebe uygulamalarının standartlaşmasını ve uluslararası muhasebe standartlarının kullanımının yaygınlaştırılmasını temel amaç olarak benimsemiştir. Bu amaçla yayınlanan bütün standartlar bir set halinde "Uluslararası Finansal Raporlama Standartları" adıyla tanımlanmıştır. Uluslararası finansal raporlama standartlarını birebir uygulama konusunda ilke kararını alan Türkiye Muhasebe Standartları Kurulu ile IASB arasında yapılan sözleşme kapsamında uluslararası muhasebe standartlarının Türkçe çevirileri Türk Muhasebe Standartları olarak yayımlanmıştır (Akdoğan, 2007: 102). Günümüzde Uluslararası Muhasebe ve Finansal Raporlama Standartları ile ilgili çalışmalar Kamu Gözetimi Muhasebe ve Denetim Standartları Kurumu (KGK) tarafından gerçekleştirilmektedir ve TFRS kodlu 16 adet TMS kodlu 25 adet standart bulunmaktadır (KGK, 2019).

Muhasebe standartlarında yaşanan gelişmeler, muhasebe standartları konusunda eğitimli meslek mensubu ihtiyacını da beraberinde getirmiştir. Ortaya çıkan bu ihtiyacın giderilmesinde üniversitelere büyük pay düşmektedir. Dolayısıyla ögrencilerin muhasebe standartları ile ilgili bilgi sahibi olmaları ve standartlar konusunda donanımlı bir şekilde mezun olmaları gerekmektedir (Çil Koçyiğit, Elitaş ve İşüvven, 2016: 60). $\mathrm{Bu}$ nedenle muhasebe meslek mensubu adayı olan öğrencilerin muhasebe ve finansal raporlama standartlarına yönelik ilgi düzeyi, beklenti ve farkındalıklarının tespiti önem taşımaktadır.

$\mathrm{Bu}$ araştırmada Giresun Üniversitesi İktisadi ve İdari Bilimler Fakültesi İşletme Bölümü öğrencilerinin Türkiye Muhasebe Standartları ve Türkiye Finansal Raporlama Standartlarına ilişkin ilgi düzeyi, beklenti ve farkındalıklarının ortaya konulması amaçlanmıştır. Araştırma sonucunda öğrencilerin muhasebe ilgi düzeyi ve meslekte çalışma arzusu ile muhasebe ve finansal raporlama standartlarına yönelik farkındalık düzeyi arasında anlamlı bir ilişki olduğu belirlenmiştir. Elde edilen bu sonuçların literatürdeki benzer araştırma sonuçlarından farklı bir özellik gösterdiği söylenebilir.

\section{KAVRAMSAL ÇERÇEVE}

Muhasebe alanında ortak bir dil oluşturulmasına yönelik çalışmaların 1960'lı yıllarda başlamış olmasına rağmen bu fikir somut olarak ilk kez 1972 yılında onuncusu gerçekleştirilen Uluslararası Muhasebecilik Kongresi'nde ele alınmıştır. 1973 yılında Kanada, Almanya, Amerika ve İngiltere gibi ülkelerin de dahil olduğu 10 ülke arasında yapılan bir anlaşma ile Uluslararası Muhasebe Standartları Komitesi (International Accounting Standards Committee-IASC)'nin kurulması ve böylelikle Uluslararası Muhasebe Standartlar1UMS (International Accounting Standards-IAS)'nı oluşturmak için çalışmalara başlanmıştır. 1977 yılında toplanan 11. Dünya Muhasebeciler Kongresinde Uluslararası Muhasebeciler Federasyonu (IFAC) kurulmuştur. IFAC ilerleyen yıllarda IASC'ı uluslararası muhasebe standartları yapıcısı olarak tanımıştır. 1989

Selçuk Üniversitesi Sosyal Bilimler Meslek Yüksekokulu Dergisi, Yıl: 2020 Cilt: 23 Sayı:1 
yılında Avrupa Muhasebeciler Federasyonu (FEE) muhasebe standartlarının küresel çapta uyumluluğunu artırmak için IASC ile anlaşmaya varmıştır. 2002 yılında Finansal Muhasebe Standartları Kurulu (FASB) ile yapılan Norwalk anlaşması sonucu Amerika Genel Kabul Görmüş Muhasebe Prensipleri (US-GAAP) ile Uluslararası Finansal Raporlama Standartları'nın uyumlu hale getirilmesi için çeşitli kararlar alınmıştır (Aysan, 2008: 46-48). Uluslararas1 Muhasebe Standartları Kurulu (International Accounting Standards Boards-IASB), 2001 yılında Uluslararas1 Muhasebe Standartları Komitesi'nin yeniden yapılandırılmas1 ile oluşmuştur. (Gökçen vd., 2015: 125) Kurul, muhasebe uygulamalarının uluslararası düzeyde uyumlu hale getirilmesi için TFRS kodlu 16 adet TMS kodlu 41 adet standart yayınlamıştır. 2005 yılından itibaren Avrupa Birliği üyesi ülkeler ve aday ülkelerde de UMS/UFRS uygulanmaktadır (Altıntaş, 2011: 166).

Türkiye'de muhasebe standartlarının gelişiminde ilişkilerin yoğun olduğu ülkelerin etkisi altında kalındığı görülmektedir. Muhasebe uygulamalarında 1950'li yıllara kadar Fransız ve Alman sistemi örnek alınırken ilerleyen dönemlerde ABD ile olan ilişkilerin artmasıyla Amerikan sistemi etkili olmuştur. Avrupa Birliği üyeliği başvurusuyla 1987 yılından itibaren $\mathrm{AB}$ uygulamalarının etkisi görülmektedir (Kocamaz, 2012: 111). Türkiye'de işletmelerin muhasebe kaydı, finansal tablolarının hazırlanması ve raporlanmasına ilişkin düzenlemeler Türk Ticaret Kanunu (TTK ) ve vergi yasaları ile yapılmıştır (Sayar, 2002: 77). Bu düzenlemelere ek "Kamu İktisadi Teşekkülleri Tekdüzen Muhasebe Sistemi" hazırlanmıştır. Muhasebe alanında standartlaşmayı sağlamak adına Maliye Bakanlığı tarafından "Muhasebe Sistemi Uygulama Genel Tebliği” (MSUGT) uygulamaya konulmuştur (Erdoğan ve Dinç, 2009: 156). Muhasebe uygulamalarının gelişmesine katkı sağlayan 3568 sayılı "Serbest Muhasebecilik, Serbest Muhasebeci Mali Müşavirlik ve Yeminli Mali Müşavirlik Kanunu” 1989 yılında yürürlüğe girmiştir. Kanunun yürürlüğe girmesinden sonra Türkiye Serbest Muhasebeci Mali Müşavirler ve Yeminli Mali Müşavirler Odaları Birliği (TÜRMOB) oluşturulmuştur. Türkiye'deki muhasebe standartlarının gelişimini sağlamak için 1995 yılında TÜRMOB tarafindan Türkiye Muhasebe ve Denetim Standartları Kurulu (TMUDESK) kurulmuştur. (Pekdemir, 2003: 22-23). TMUDESK' in amacı ulusal düzeyde genel kabul gören Türkiye Muhasebe Standartlarını oluşturup uygulanmasını sağlamak ve bu standartları Uluslararası Muhasebe Standartları ile uyumlu hale getirmektir (Koç Yalkın, 2001: 3). TMUDESK'in yanı sıra Sermaye Piyasası Kurulu (SPK), Maliye Bakanlığı gibi kurullar da ülkemizde muhasebe standartlarının oluşmasına katkıda bulunmuştur. Muhasebe standartlarının oluşturulması ile ilgilenen birden fazla kurumun olması bu konuda karışıklı̆̆a sebep olduğundan muhasebe standartları yayınlamak için Türkiye Muhasebe Standartları Kurulu (TMSK) oluşturulmuştur (Erdoğan ve Dinç, 2009: 156). IASB'ın yayınladığı Uluslararası Muhasebe Standartları (IAS), Uluslararası Finansal Raporlama Standartları (IFRS) ve yorumlarının Türkçe' ye çevrilmesiyle Türkiye Muhasebe Standartları/Türkiye Finansal Raporlama Standartları (TMS/ TFRS) oluşturulmuştur (Akdoğan, 2007, 101102).

6102 sayılı TTK'nın ilgili maddeleri uyarınca kanunlara göre defter tutmakla yükümlü olan tacirlerin, finansal tablolarını KGK tarafından yayımlanan TMS'lere uygun hazırlaması gerektiği öngörülmüştür. Ayrıca KGK farklı sektörler ve işletme büyüklükleri için düzenlemeler yapmaya yetkili kılınmıştır. Bu kapsamda KGK bağımsız denetime tabi işletmelerin TFRS uygulamalarını öngörmüş fakat TFRS uygulama kapsamının bağımsız denetim kapsamı ile aynı belirlenmesinin ilerleyen yıllarda işletmelere ek maliyet yükleyeceği değerlendirilmiştir. Bu nedenle KGK 2014 yılında TFRS uygulama kapsamını bağımsız denetim kapsamından ayırarak TFRS uygulama kapsamını kamu yararını ilgilendiren kuruluşlar ile sınırlandırmıştır. Bunun dışında kalan işletmelerin isteğe bağlı olarak TFRS uygulamasına izin verilmiştir. TFRS uygulamayan işletmelerin uygulayacağı finansal raporlama çerçevesi ise Maliye Bakanlığı tarafından yayımlanan MSUGT olarak belirlenmiştir. Ardından 2018 yılında uygulamaya konulan "Büyük ve Orta Boy İşletmeler İçin Finansal Raporlama Standardı" (BOBİ FRS) ile bağımsız denetime tabi olup TFRS uygulamayan işletmelerin uygulaması gereken finansal raporlama çerçevesi belirlenmiştir. Böylece bağımsız denetime tabi olup TFRS uygulamayan işletmelerde uygulanan MSUGT ve İlave Hususlar'ın yerini BOBİ FRS almıştır (KGK, 2019). Yine KGK tarafindan, küçük ve mikro işletmeler için raporlamada uygulanmak üzere "Küçük ve Mikro İşletmeler İçin Finansal Raporlama Standardı" (KÜMİ FRS) adlı standart taslak metni oluşturmuş ve metin 2019 yılı Şubat ayı itibariyle kamuoyunun görüşlerine açılmıştır (Gökçen, Öztürk ve Güleç, 2019: 414).

Türkiye'de uluslararası standartlar temelinde oluşturulan finansal raporlama çerçeveleri ve yaşanan köklü değişimler muhasebe eğitimine yönelik dönüşüm ihtiyacını da beraberinde getirmiştir. Bu kapsamda meslek mensuplarının ve öğrenimine devam eden meslek adayı öğrencilerin değişen standartlara uyum sağlayabilmesi standartlar ile ilgili eğitim almaları ile mümkün olmaktadır. Bu nedenle muhasebe eğitiminin muhasebe standartlarını kapsayacak nitelikte olması önem taşımaktadır (Gökçen vd., 2015: 126; Dalgar vd, 2011: 220). Mesleki eğitimin temeli olan muhasebe eğitiminde amaç mesleğin icrası için gerekli donanımın kişiye kazandırılmasıdır. Mesleğe ilişkin ulusal ve uluslararası standartlara göre düzenlenen bilimsel yeterlilik 
kriterlerine uygun hazırlanan ders programları ile gerekli donanım öğrencilere verilmelidir (Zaif ve Ayanoğlu, 2007: 117).

Türkiye'de muhasebe eğitimi lise düzeyinde başlamakla birlikte ön lisans düzeyinde meslek yüksekokullarında, lisans düzeyinde ise İşletme, İktisadi ve İdari Bilimler, Siyasal Bilgiler gibi fakültelerde işletme, muhasebe, vb. bölümlerde verilmektedir. Fakülte ve meslek yüksekokullarında genellikle Genel Muhasebe, Muhasebede Dönemsonu İşlemleri, Şirketler Muhasebesi ve Maliyet Muhasebesi adlı dersler yer almaktadır. Muhasebe standartları ile ilgili dersler daha çok mesleğe yönelik bir konu olduğundan çoğunlukla yüksek lisans düzeyinde verilmektedir. Ayrıca lisans düzeyinde işletme, muhasebe ve finans programlarında ve ön lisans düzeyinde muhasebe ve vergi uygulamaları ile işletme programlarında seçmeli ders olarak da muhasebe standartları ile ilgili dersler okutulmaktadır (Dalgar vd., 2011: 220; Kutlu, 2010: 235-236).

\section{LITERATÜR ARAŞTIRMASI}

Literatürde muhasebe eğitimi verilen öğrencilerin TMS/TFRS hakkındaki ilgi, beklenti ve farkındalık düzeyinin tespitine ilişkin olarak yapılmış olan akademik çalışmalar aşağıda özetlenmiştir. Araştırma, Türkiye özelinde yapılan bir çalışma olduğu için yabancı akademik çalışmalara değinilmemiştir.

Dalgar vd. (2011), "Muhasebe Öğrenimi Gören Öğrencilerin TMS / TFRS Hakkındaki Farkındalıklarına Yönelik Bir Araştırma" adlı çalışmada muhasebe eğitimi alan öğrencilerin Türkiye Muhasebe Standartları konusunda farkındalık düzeyini belirlemeyi amaçlamıştır. Mehmet Akif Ersoy Üniversitesine bağlı meslek yüksekokullarının muhasebe ve vergi uygulamaları bölümünde eğitim alan öğrencilere anket uygulanmıştır. Araştırmanın sonucunda muhasebe mesleğine ilgisi yüksek olan ve mesleği icra etmeyi düşünen öğrencilerin TMS/TFRS hakkındaki farkındalığının daha fazla olduğu belirlenmiştir.

Kurnaz (2012), "Statistical Analysis of the Factors Affecting Accounting Students' Awareness of the TAS (Turkish Accounting Standards) and TFRS (Turkish Financial Reporting Standards)" adlı çalışmada üniversite öğrencilerinin standartlar hakkında ilgi düzeyi ve farkındalığını ölçmeyi amaçlamıştır. Çalışmada, mezun olduktan sonra muhasebe mesleğine başlamak isteyen öğrencilerin TMS/TFRS hakkında farkındalığının daha yüksek olduğu sonucuna ulaşılmıştır.

Yıldız ve Yanık (2013), "Yükseköğretimde Öğgrenim Gören Öğrencilerin Muhasebe ve Finansal Raporlama Standartları Hakkındaki Algıları: Ampirik Çalışma” adlı araştırmada muhasebe eğitimi alan ögrencilerin Türkiye Muhasebe Standartları konusunda algılarını ortaya koymak için Kocaeli Üniversitesi İktisadi ve İdari Bilimler Fakültesi İşletme Bölümü öğrencilerine anket uygulaması yapılmıştır. Araştırma sonucunda muhasebe mesleğinde çalışmayı düşünen öğrencilerin Türkiye Muhasebe Standartları hakkındaki bilgi düzeyinin meslekte çalışmayı düşünmeyen öğrencilere göre daha fazla olduğu belirlenmiş ve öğrencilerin muhasebe standartlarına ilişkin algılarında mesleğe ilgisi yüksek olan öğrenciler ile olmayan öğrenciler arasında fark bulunmadığı sonucuna ulaşılmıştır.

Yanık ve Yıldız (2013), “ Lisans ve Ön Lisans Düzeyinde Öğrenim Gören Öğrencilerin Muhasebe Standartları Hakkındaki Algılarının Karşılaştııılması: Bir Araştırma” adlı çalışmada lisans ve ön lisans seviyesinde eğitim alan öğrencilerin TMS/TFRS hakkındaki algılarını karşılaştırmayı amaçlamıştır. Kocaeli Üniversitesi’nde lisans düzeyinde İşletme Bölümünde ve ön lisans düzeyinde Muhasebe ve Vergi Uygulamaları Bölümünde eğitim alan öğrenciler üzerinde anket uygulaması yapılmıştır. Araştırma sonucunda muhasebe mesleğine ilgisi yüksek olan ve meslekte çalışmayı isteyen lisans ve ön lisans düzeyinde eğitim alan öğrencilerin algıları arasında fark olmadığı belirlenmiştir.

Yanık vd. (2013), "Muhasebe Eğitimi Gören Ön Lisans Öğrencilerinin Muhasebe Standartları Hakkındaki Algıları Üzerine Bir Araştırma " adlı çalışmada ön lisans düzeyinde muhasebe eğitim alan öğrencilerin Türkiye Muhasebe Standartları hakkındaki algılarını tespit etmeyi amaçlamıştır. Kocaeli Üniversitesi Meslek Yüksekokulu Muhasebe ve Vergi Uygulamaları Bölümünde yapılan araştırma sonucunda öğrencilerin muhasebe standartlarına yönelik algılarında, mesleğe ilgisi yüksek ve düşük öğrenciler arası anlamlı farklar olduğu belirlenirken ticaret lisesinden mezun öğrenciler ve diğer liselerden mezun olan öğrenciler arasinda anlamlı bir farklılığa ulaşılmamıştır.

Y1lmaz, Şahin ve Çankaya (2014), "Orta ve Doğu Karadeniz Bölgesindeki Öğrenci, Akademisyen ve Uygulayıcıların TMS/TFRS Farkındalıkları ve Görüşleri Üzerine Bir Çalışma” adlı araştırmada TMS'nin uygulanabilirliği hakkında farklı grupların farkındalığını ölçmeyi amaçlamıştır. Öğrencilerin yapmayı düşündüğ̈̈ meslek ile TMS/TFRS hakkında farkındalık düzeyi arasında anlamlı fark tespit edilirken, işletme son sınıf öğrencilerinin TMS/TFRS hakkında farkındalığa sahip olmadıkları sonucuna ulaşılmıştır.

Karakaya Demirkutlu (2014), "İşletme Lisans Öğrencilerinin Türkiye Muhasebe/Finansal Raporlama Standartları Hakkındaki İlgi Düzeyleri, Beklentileri ve Farkındalıkları: Gazi Üniversitesi İktisadi ve İdari 
Bilimler Fakültesi Örneği” adlı çalışmada işletme bölümü öğrencilerinin TMS/TFRS hakkında ilgi düzeyi, beklenti ve farkındalıklarını ölçmeyi amaçlamıştır. İşletme Bölümü son sınıf öğrencilerine uygulanan anket sonucunda öğrencilerin muhasebe alanında staj/iş tecrübesi durumu ile TMS/TFRS farkındalığı arasında anlamlı fark olmadığı sonucuna ulaşılmıştır. Ayrıca muhasebeye ilgisi yüksek olan öğrencilerin farkındalığının daha yüksek olduğu belirlenmiştir.

Elitaş, İşgüven ve Çil Koçyiğit (2016), "Lisans Öğrencilerinin TMS/TFRS Hakkındaki Farkındalıklarına Yönelik Bir Araştırma: Yalova Üniversitesi İktisadi ve İdari Bilimler Fakültesi Örneği” adlı çalışmada İşletme ile Uluslararası Ticaret ve Finansman Bölümünde eğitim alan öğrencilerin farkındalığını belirlemeyi amaçlanmıştır. İşletme Bölümü öğrencilerinin TMS/TFRS hakkındaki farkındalıkları ile Uluslararası Ticaret ve Finansman Bölümü öğrencilerinin farkındalıkları arasında anlamlı düzeyde farklılık olmadığı sonucuna ulaşılmıştır.

Kara, Tuna ve Hitay (2016), "Üniversitelerde Uluslararası Muhasebe Standartları Ĕgitimi ve Balıkesir Üniversitesi'nde Bir Araştırma" adlı çalışmada muhasebe eğitimi verilen üniversitelerde TMS/TFRS'ye verilen önem ile öğrencilerin standartlar konusundaki farkındalığını ölçmeyi amaçlamıştır. Araştırma sonucunda TMS/TFRS hakkında farkındalığın oluşmadığı ve öğrenim türü ve muhasebe alanında tecrübe ile standartların algılanması arasında anlamlı bir farklılık olmadığı belirlenmiştir.

Turhan ve Oğuz (2016), "İ̧sletme Lisans Öğrencilerinin Türkiye Muhasebel Finansal Raporlama Standartları Hakkındaki Ilgi Düzeyleri, Beklentileri ve Farkındalıklarl: Balıkesir Üniversitesi İktisadi ve İdari Bilimler Fakültesi Örneği” adlı çalışmada İşletme Bölümü son sınıf öğrencilerine anket uygulamıştır. TMS/TFRS derslerini zorunlu olarak alan ve almayan öğrenciler arasında, ilgi düzeyi ve farkındalık bakımından anlamlı düzeyde farklılık olduğu belirlenmiştir.

Erol Fidan ve Uysal (2017), "Türkiye Muhasebe ve Finansal Raporlama Standartlar Konusunda Üniversite Ögrrencilerinin Algı Düzeylerinin Ölçülmesi: Bilecik Şeyh Edebali Üniversitesi Örneği” adlı çalışmada öğrencilerin TMS/TFRS konusundaki bilgi ve algı düzeyini belirlemeyi amaçlamıştır. Yaş, bölüm, sınıf gibi değişkenler açısından öğrencilerin Türkiye Muhasebe Standartlarını algılama düzeyi arasında anlamlı farklilıklar bulunmuştur.

K1llı ve Küçüktüfekçi (2018), "Türkiye'deki Üniversitelerde TMS/TFRS Eğitimi Üzerine Bir Araştırma" adlı çalı̧̧mada Türkiye'deki devlet ve vakıf üniversitelerinde muhasebe eğitimi verilen lisans ve lisansüstü programlarda muhasebe ve finansal raporlama standartlarına ilişkin derslerin verilme düzeyini araştırmıştır. Araştırma sonucunda TMS/TFRS eğitimine gereken önemin henüz verilmediği belirlenmiştir.

Şimşek ve Şimşek (2019), "Muhasebe Eğitimi Alan Lisans Öğrencilerinin TFRS (Türkiye Finansal Raporlama Standartlarl) / TMS (Türkiye Muhasebe Standartlarl) Farkındalıklarının Belirlenmesine Yönelik Bir Araştırma" adlı çalışmada muhasebe eğitimi alan lisans öğrencilerinin TMS/TFRS konusundaki farkındalıklarını belirlemeyi amaçlamıştır. Bu kapsamda Kastamonu Üniversitesi İktisadi ve İdari Bilimler Fakültesi’nin Bankacılık ve Finans ile İşletme Bölümleirnde öğrenim gören 237 öğrenciye anket uygulamıştır. Araştırma sonucunda TMS/TFRS farkındalık düzeyi açısından İşletme Bölümü öğrencileri ile Bankacılık ve Finans Bölümü öğrencileri arasında anlamlı farklılık olduğu belirlenmiştir.

\section{ARAŞTIRMA}

Çalışmanın bu bölümünde araştırmanın amacı, kapsamı, yöntemi ve anket çalışmasına bağlı elde edilen verilerin analizi yer almaktadır.

\subsection{Araştırmanın Amacı}

Araştırmada, Giresun Üniversitesi İktisadi ve İdari Bilimler Fakültesi İşletme Bölümü öğrencilerinin TMS/TFRS hakkındaki ilgi düzeyleri, beklentileri ve farkındalıklarının düzeyinin tespiti amaçlanmıştır.

\subsection{Araştırmanın Kapsamı ve Yöntemi}

Araştırmanın ana kütlesini, Giresun Üniversitesi İktisadi ve İdari Bilimler Fakültesi İşletme Bölümü üçüncü ve dördüncü sınıf öğrencileri oluşturmaktadır. Ana kütlenin belirlenmesinde öğrencilerin ilgili dönemde seçmeli veya zorunlu olarak TMS/TFRS ve muhasebeye ilişkin dersler alıyor olmaları etkili olmuştur. $\mathrm{Bu}$ kapsamda programa kayıtlı birinci ve ikinci öğretim toplam öğrenci sayısı 328'dir.

Örneklemin ana kütleyi temsil oranı önem arz ettiğinden, sayısı belirli bir evrende örneklemin ana kütleyi temsil oranının hesaplanmasında kullanılan aşağıdaki formülden yararlanılmıştır (Atıgan ve Yükselen, 2018: 41).

$$
\mathrm{n}=\frac{\mathrm{Nt}^{2} \mathrm{pq}}{\mathrm{d}^{2}(\mathrm{~N}-1)+\mathrm{t}^{2} \mathrm{pq}}
$$


Formüle göre araştırmanın yapıldığı evren için örneklem sayısının en az 177 olması gerektiği hesaplanmıştır. Anketler 188 öğrenciye dağıtılmış olup, dağıtılan tüm anketlerden geri dönüş sağlanmıştır. Anketlerden 3 tanesi soruların cevaplanmaması nedeniyle değerlendirmeye alınmamış ve analizler 185 anket üzerinden yapılmıştır. Araştırmada kullanılan ankette, öğrencilerin demografik özelliklerini, TMS/TFRS hakkında ilgi düzeyi, beklenti ve farkındalıklarını ölçmek için yöneltilen soruların yanı sıra muhasebeye olan ilgi düzeylerini de ölçmeye yönelik sorulara yer verilmiştir. Anket sorularının hazırlanmasında Turhan ve Oğuz'un (2016), çalışmalarında kullandığı 5'li Likert Ölçeğgi ${ }^{1}$ kullanılmış ve verilerin analizi IBM SPSS STATISTICS 24 paket programı ile gerçekleştirilmiştir.

\subsection{Araştırma Bulguları}

Bu bölümde araştırmanın genel bulgularına ve öğrencilerin TMS/TFRS ile ilgili ilgi düzeyi, beklenti ve farkındalıklarının ölçümüne ilişkin analizlere yer verilmiştir.

\subsubsection{Katılımcıların Demografik Özelliklerine Yönelik Bulgular}

Katılımcıların demografik özelliklerine ilişkin bilgiler Tablo 1'de ayrıntılı olarak yer verilmiştir. Bu kapsamda araştırmaya katılan öğrencilerin \%46'sının 23-25 yaş aralığında \%50,8'inin 20-22 yaş aralığında olduğu gözlemlenmiştir. Katılımcıların \%51,9'nun birinci öğretimde okuduğu ve ağırlıklı olarak düz lise mezunu olduğu belirlenmiştir. Öğrenciler çoğunlukla ailelerinin Karadeniz Bölgesinde yaşadığını ve yerleşim türü olarak ilde ikamet ettiğini belirtmiştir.

Tablo 1: Katılımcıların Demografik Özellikleri

\begin{tabular}{|c|c|c|c|}
\hline & & Sayı & Yüzde \\
\hline \multirow{3}{*}{ Yaş } & $20-22$ Yaş Aralığ 1 & 94 & 50,8 \\
\hline & $23-25$ Yaş Aralığ 1 & 85 & 46 \\
\hline & 26 Yaş ve Üzeri & 6 & 3,2 \\
\hline \multirow{2}{*}{ Cinsiyet } & Kadın & 97 & 52,4 \\
\hline & Erkek & 88 & 47,6 \\
\hline \multirow{2}{*}{ Öğrenim Türü } & Birinci Öğretim & 96 & 51,9 \\
\hline & İkinci Öğretim & 89 & 48,1 \\
\hline \multirow{4}{*}{ Mezun Olunan Lise Türü } & Düz Lise & 92 & 49,7 \\
\hline & Anadolu Lisesi & 48 & 25,9 \\
\hline & Meslek Lisesi & 34 & 18,4 \\
\hline & Diğger Liseler & 11 & 5,9 \\
\hline \multirow{4}{*}{ Ailenizin Yaşadığı Yerleşim Türü } & $\dot{\mathrm{II}} \mathrm{l}$ & 55 & 29,7 \\
\hline & Büyükşsehir & 52 & 28,1 \\
\hline & İlçe & 45 & 24.3 \\
\hline & Köy & 33 & 17,8 \\
\hline \multirow{8}{*}{ Ailenizin Yaşadığı Bölge } & Karadeniz Bölgesi & 102 & 55,1 \\
\hline & Marmara Bölgesi & 21 & 11,4 \\
\hline & İç Anadolu Bölgesi & 19 & 10,3 \\
\hline & Akdeniz Bölgesi & 16 & 8,6 \\
\hline & Ege Bölgesi & 10 & 5,4 \\
\hline & Doğu Anadolu Bölgesi & 7 & 3,8 \\
\hline & GDA Bölgesi & 7 & 3,8 \\
\hline & Diğer & 3 & 1,6 \\
\hline
\end{tabular}

\footnotetext{
${ }^{1}$ 5'li Likert Ölçeği, “1= Kesinlikle Katılmıyorum” - “5= Kesinlikle Katılıyorum” şeklinde kullanılmıștır.
} 


\subsubsection{Güvenilirlik ve Normallik Analizi}

Araştırma kapsamında kullanılan ölçeğin güvenilirliğini belirlemek adına öncelikle güvenilirlik analizi gerçekleştirilmiştir. Ardından verilerin normal dağılım gösterip göstermediğini belirlemek için ilgi düzeyi, beklenti ve farkındalığı ölçmeye yönelik anket sorularına normallik testi uygulanmıştır. Verilerin normal dağılım gösterip göstermediğinin belirlenmesi uygulanacak analizlerin tespitinde önem taşımaktadır.

Güvenilirlik (reliability), bir araştırmada kullanılan veri toplama yönteminin, aynı konuda yapılan farklı bir araştırmada da aynı ya da benzer sonuçlar vermesi özelliğidir (Aziz, 2017: 59). Araştırma verilerinin elde edilmesi için kullanılan anket formunda katılımcıların demografik özelliklerine ek TMS/TFRS hakkında ilgi düzeyleri, beklenti ve farkındalığını ölçmek için kullanılan toplam 36 soru yer almaktadır. Anketlerden elde edilen verilerin güvenilirliği Cronbach's Alpha katsayısı ile hesaplanmıştır ve gerçekleştirilen analiz tekniklerinin sonucu Cronbach's Alpha katsayısının 0,90 olduğu tespit edilmiştir. Bu kapsamda araştırmada kullanılan ölçeğin güvenilirlik düzeyinin sosyal bilimler için yüksek olduğu belirtilebilir.

Çalışmada kullanılan anket verilerinin normal dağılım gösterip göstermediğini belirlemek amacıyla gerçekleştirilen Kolmogorov-Smirnov ve Shapiro-Wilk test sonuçlarına Tablo 2'de ayrıntılı olarak yer verilmiştir.

Tablo 2: Normal Dağılımı Belirlemeye Yönelik Test Sonuçları

\begin{tabular}{|l|c|c|c|c|c|c|}
\hline \multirow{2}{*}{ Değişken } & \multicolumn{3}{|c|}{ Kolmogorov-Smirnov } & \multicolumn{3}{c|}{ Shapiro-Wilk } \\
\cline { 2 - 7 } & Statistic & Df & Sig. & Statistic & df & Sig. \\
\hline S1 &, 290 & 185 &, 000 &, 854 & 185 &, 000 \\
\hline S2 &, 350 & 185 &, 000 &, 790 & 185 &, 000 \\
\hline S3 &, 276 & 185 &, 000 &, 855 & 185 &, 000 \\
\hline S4 &, 243 & 185 &, 000 &, 845 & 185 &, 000 \\
\hline S5 &, 329 & 185 &, 000 &, 818 & 185 &, 000 \\
\hline S6 &, 235 & 185 &, 000 &, 861 & 185 &, 000 \\
\hline S7 &, 266 & 185 &, 000 &, 845 & 185 &, 000 \\
\hline S8 &, 194 & 185 &, 000 &, 895 & 185 &, 000 \\
\hline S9 &, 220 & 185 &, 000 &, 855 & 185 &, 000 \\
\hline S10 &, 294 & 185 &, 000 &, 863 & 185 &, 000 \\
\hline S11 &, 242 & 185 &, 000 &, 855 & 185 &, 000 \\
\hline S12 &, 293 & 185 &, 000 &, 838 & 185 &, 000 \\
\hline S13 &, 190 & 185 &, 000 &, 885 & 185 &, 000 \\
\hline S14 &, 180 & 185 &, 000 &, 898 & 185 &, 000 \\
\hline S15 &, 333 & 185 &, 000 &, 826 & 185 &, 000 \\
\hline S16 &, 326 & 185 &, 000 &, 824 & 185 &, 000 \\
\hline S17 &, 286 & 185 &, 000 &, 857 & 185 &, 000 \\
\hline S18 &, 192 & 185 &, 000 &, 909 & 185 &, 000 \\
\hline S19 & & 185 &, 000 &, 852 & 185 &, 000 \\
\hline S20 & & & & &, 000 \\
\hline
\end{tabular}

Normallik testlerinin sonucunda p değeri 0,05 ’ten düşük çıkması verilerin normal dağılım sergilemediğini anlamına gelmektedir. Bu durumda verilerin analizi için uygulanacak testlerin non-parametrik testler olması gerekmektedir. Katılımcıların ilgi düzeyi, beklenti ve farkındalıklarını belirlemeye yönelik testlerden önce Tablo 3'te verilerin ortalama ve standart sapmaları gösterilmiştir. 
Tablo 3: İlgi Düzeyi, Beklentileri ve Farkındalığa Yönelik Ortalama ve Standart Sapma Değerleri

\begin{tabular}{|c|c|c|c|c|}
\hline & & $\begin{array}{l}\text { Katılımcı } \\
\text { Sayısı }\end{array}$ & Ortalama & $\begin{array}{c}\text { Standart } \\
\text { Sapma }\end{array}$ \\
\hline S1 & Bölümde TMS/TFRS dersleri mutlaka verilmelidir. & 185 & 3,6919 & ,85159 \\
\hline S2 & $\begin{array}{l}\text { TMS/TFRS dersini anlatan sorumluların yeterliliăgi, } \\
\text { araç- gereçler verimliliği etkilemektedir. }\end{array}$ & 185 & 3,8595 & ,72362 \\
\hline S3 & TMS/TFRS'ler mesleki açıdan önemli ve gereklidir. & 185 & 3,6432 & ,78177 \\
\hline S4 & $\begin{array}{l}\text { TMS/TFRS'ler vergi amaçlı muhasebe yerine bilgi } \\
\text { amaçlı muhasebeyi ön plana çikartır. }\end{array}$ & 185 & 3,5459 & ,76563 \\
\hline S5 & $\begin{array}{l}\text { TMS/TFRS, İngilizce yayımlanan uluslararası } \\
\text { muhasebe standartlarının birebir çevirisidir. }\end{array}$ & 185 & 3,1297 & ,76927 \\
\hline S6 & TMS/TFRS Dünya'da ortak bir muhasebe dilidir. & 185 & 3,3568 & ,88605 \\
\hline S7 & TMS/TFRS konusunda ödev, vb. araştırma yaptım. & 185 & 2,2703 & 1,18525 \\
\hline S8 & $\begin{array}{l}\text { TMS/TFRS konuları ile tekdüzen hesap planı } \\
\text { karşılaştırması yapabilirim. }\end{array}$ & 185 & 2,4432 & 1,04687 \\
\hline S9 & TMS/TFRS konularıyla ilgili dersler aldım. & 185 & 2,3622 & 1,24397 \\
\hline S10 & $\begin{array}{l}\text { TMS/TFRS'de finansal tabloların düzenlenme şekli } \\
\text { ve isimleri değişmektedir. }\end{array}$ & 185 & 2,9243 & ,94679 \\
\hline S11 & $\begin{array}{l}\text { TMS/TFRS'lere uygun bilanço ve gelir tablosu } \\
\text { ayrıntılı ve karşılaştırılması mümkün bilgiler sağlar. }\end{array}$ & 185 & 3,2973 & ,91083 \\
\hline S12 & $\begin{array}{l}\text { TMS/TFRS'ler finansal tabloların oluşturulmasında } \\
\text { tekdüzelik sağlar. }\end{array}$ & 185 & 3,1297 & ,84983 \\
\hline S13 & TMS/TFRS ifadeleri ile ilgili bilgi sahibiyim. & 185 & 2,7351 & 1,09847 \\
\hline S14 & $\begin{array}{l}\text { Türkiye Genel Kabul Görmüş Muhasebe İlkeleri ile } \\
\text { TMS/TFRS arası farklar hakkında bilgi sahibiyim. }\end{array}$ & 185 & 2,5243 & 1,10370 \\
\hline S15 & $\begin{array}{l}\text { TMS/TFRS'ler büyük işletmeler ve KOBİ'ler için } \\
\text { ayrı olarak yayınlanmaktadır. }\end{array}$ & 185 & 2,8270 & ,90429 \\
\hline S16 & $\begin{array}{l}\text { Ülkemizde şirketlerin çoğu TMS/TFRS'yi } \\
\text { uygulamaya hazırlanmaktadır. }\end{array}$ & 185 & 2,9459 & 82574 \\
\hline S17 & TMS/TFRS'ler işletme paydaşlarını etkiler. & 185 & 3,0973 & ,94480 \\
\hline S18 & TMS/TFRS'ye ilgi duyuyorum. & 185 & 2,6973 & 1,09109 \\
\hline S19 & $\begin{array}{l}\text { Bölümde TMS/TFRS ile ilgili daha fazla ders } \\
\text { açılacak olursa, bu dersleri alırım/seçerim. }\end{array}$ & 185 & 3,2324 & 1,07087 \\
\hline S20 & $\begin{array}{l}\text { Dersin uygulamaya yönelik anlatılması ve } \\
\text { sevdirilmesi başarımı pozitif etkiler. }\end{array}$ & 185 & 3,8541 & 1,05568 \\
\hline
\end{tabular}

\subsubsection{Katılımcıların TMS/TFRS Hakkındaki İlgi Düzeylerine Yönelik Analizler}

Katılımcıların TMS/TFRS ile ilgili ilgi düzeyini belirlemek için gerçekleştirilen analizlerden önce ögrencilerin muhasebeye olan ilgi düzeyleri incelenmiştir. Bu kapsamda Tablo 4'te katılımcıların muhasebe alanına yönelik ilgi düzeylerine ayrıntılı olarak yer verilmiştir. Tablodan görüleceği üzere analiz sonucunda öğrencilerin çoğunluğunun muhasebe ilgi düzeyinin orta düzeyde olduğu belirlenmiştir. 
Tablo 4: Katılımcıların Muhasebeye İlgi Düzeyinin Tespitine İlişkin Frekans Değerleri

\begin{tabular}{|c|c|c|c|}
\hline \multicolumn{2}{|c|}{} & Frekans & Yüzde \\
\hline \multirow{4}{*}{ Muhasebeye Yönelik İlgi Düzeyiniz } & Çok Yüksek & 8 & 4,3 \\
\cline { 2 - 4 } & Yüksek & 30 & 16,2 \\
\cline { 2 - 4 } & Orta & 97 & 52,4 \\
\cline { 2 - 4 } & Düşük & 39 & 21,1 \\
\cline { 2 - 4 } & Çok Düşük & 11 & 5,9 \\
\cline { 2 - 4 } & Toplam & $\mathbf{1 8 5}$ & $\mathbf{1 0 0 , 0}$ \\
\hline
\end{tabular}

Tablo 5, katılımcıların TMS/TFRS'leri daha önce duyup- duymadıklarını ve duydularsa nereden duyduklarını belirlemeye yönelik oluşturulmuştur. Bu kapsamda öğrencilerin \%57,8'lik kısmının TMS/TFRS kavramını duyduğu ve çoğunluğun TMS/TFRS kavramını derslerden duyduğu tespit edilmiştir.

Tablo 5: Katılımcıların TMS/TFRS Kavramlarını Duyup- Duymadıklarına ve Duydularsa Nereden Duyduklarına İlişkin Frekans Analizi Sonuçları

\begin{tabular}{|l|c|c|c|}
\hline \multicolumn{2}{|c|}{} & Frekans & Yüzde \\
\hline \multirow{3}{*}{$\begin{array}{l}\text { TMS/TFRS kavramlarını daha } \\
\text { önceden duydunuz mu? }\end{array}$} & Evet & 107 & 57,8 \\
\cline { 2 - 4 } & Hayır & 78 & 42,2 \\
\cline { 2 - 4 } & Toplam & $\mathbf{1 8 5}$ & $\mathbf{1 0 0 , 0}$ \\
\hline \multirow{3}{*}{$\begin{array}{l}\text { TMS/TFRS kavramlarını } \\
\text { nereden duydunuz? }\end{array}$} & Ders & 66 & 61,7 \\
\cline { 2 - 4 } & İnternet & 27 & 25,2 \\
\cline { 2 - 4 } & Haber/Medya & 6 & 5,6 \\
\cline { 2 - 4 } & Diğer & 8 & $\mathbf{1 0 0 , 0}$ \\
\cline { 2 - 4 } & Toplam & $\mathbf{1 0 7}$ & \\
\hline
\end{tabular}

Araştırmanın bu kısmında katılımcıların ilgi düzeyini belirlemeye yönelik kullanılan hipotezler, analiz sonuçları ve yorumlara yer verilmiştir.

$H_{I}=\ddot{O} \breve{g}$ retim türü ile öğrencilerin TMS/TFRS'ye ilgi düzeyi arasında anlamlı farklılık vardır.

$\mathrm{H}_{1}$ hipotezine yönelik gerçekleştirilen Mann-Whitney U Testine ilişkin bilgilere Tablo 6'da yer verilmiştir. Analiz sonucuna göre 0,05 anlamlılıkta $(\mathrm{P})>0,05$ bulunmuş ve $\mathrm{H}_{0}$ kabul edilmiştir. Bu nedenle öğrencilerin öğretim türü ve TMS/TFRS ilgi düzeyi arası anlamlı farklılık olmadığı söylenebilir.

Tablo 6: Öğretim Türü ve TMS/TFRS İlgi Düzeyine Yönelik Test Sonuçları

\begin{tabular}{|l|c|c|c|c|}
\hline \multicolumn{1}{|c|}{ Sorular } & Mann-Whitney U & Wilcoxon W & Z & Asym. Sig. (2 tailed) \\
\hline S7 & 4010,000 & 8666,000 &,- 753 &, 451 \\
\hline S8 & 4199,500 & 8855,500 &,- 208 &, 835 \\
\hline S9 & 4184,500 & 8840,500 & -249 &, 803 \\
\hline S13 & 4229,000 & 8234,000 &,- 122 &, 903 \\
\hline S18 & 3968,500 & 7973,500 & -862 &, 388 \\
\hline S19 & 4256,000 & 8261,000 &,- 046 &, 963 \\
\hline
\end{tabular}




\section{$\mathrm{H}_{2}=$ Cinsiyet ile TMS/TFRS ilgi düzeyi arasında anlamlı farklılık vardır.}

Tablo 7'de cinsiyet ile ilgi düzeyi arası anlamlı fark olup olmadığ incelenmiştir. Bu kapsamda 0,05 anlamlılıkta $(\mathrm{P})>0,05$ bulunmuş ve $\mathrm{H}_{0}$ kabul edilmiştir. Bu sonuç katılımcıların cinsiyetleri ile ilgi düzeyi arasında anlamlı farklılık bulunmadı̆̆ını göstermektedir.

Tablo 7: Cinsiyet ile TMS/TFRS İlgi Düzeyine Yönelik Test Sonuçları

\begin{tabular}{|l|c|c|c|c|}
\hline \multicolumn{1}{|c|}{ Sorular } & Mann-Whitney U & Wilcoxon W & Z & Asym. Sig. (2 tailed) \\
\hline S7 & 3920,500 & 8673,500 &,- 999 &, 318 \\
\hline S8 & 3920,500 & 8673,500 &,- 996 &, 319 \\
\hline S9 & 3671,500 & 8424,500 & $-1,700$ &, 089 \\
\hline S13 & 4149,000 & 8902,000 &,- 339 &, 735 \\
\hline S18 & 3710,500 & 8463,500 & $-1,585$ &, 113 \\
\hline S19 & 4068,500 & 8821,500 &,- 572 &, 567 \\
\hline
\end{tabular}

$\mathrm{H}_{3}=\ddot{O} \ddot{g}$ rencilerin muhasebe ilgi düzeyi ile TMS/TFRS'ye ilgi düzeyi arasında anlamlı farklılık vardır.

$\mathrm{H}_{3}$ hipotezinin testine ilişkin sonuçları içeren Tablo 8 incelendiğinde öğrencilerin muhasebe ilgi düzeyi ile TMS/TFRS ilgi düzeyi arası 0,05 anlamlılıkta $(\mathrm{P})<0,05$ olduğu için S7, S8, S18 ve S19 değişkenlerinde anlamlı farklılık olduğu belirlenmiştir. Bu durumda muhasebe alanına ilgi düzeyi yüksek olan öğrencilerin TMS/TFRS'ye de ilgi duyduğu, TMS/TFRS'ye yönelik konuları içeren ders aç1lırsa bu dersi/dersleri seçme eğiliminde oldukları söylenebilir. Ayrıca öğrencilerin TMS/TFRS konusunda araştırma, ödev, sunum yapması ile TMS/TFRS ilgi düzeyi arasında anlamlı farklılık tespit edilmiştir. Öğrencilerin muhasebe ilgi düzeyi ile diğer değişkenler arası anlamlı farklılık bulunmamıştır.

Tablo 8: Muhasebe İlgi Düzeyi ile TMS/TFRS İlgi Düzeyi Test Sonuçları

\begin{tabular}{|l|c|c|c|}
\hline \multicolumn{1}{|c|}{ Sorular } & Chi-Square & Df & Asymp. Sig. \\
\hline S 7 & 12,802 & 4 &, 012 \\
\hline S 8 & 11,172 & 4 &, 025 \\
\hline S 9 & 1,574 & 4 &, 813 \\
\hline S 13 & 8,760 & 4 &, 067 \\
\hline S 18 & 26,971 & 4 &, 000 \\
\hline S 19 & 31,809 & 4 &, 000 \\
\hline
\end{tabular}

\section{$\mathrm{H}_{4}=$ Muhasebe meslek tercihi ile TMS/TFRS ilgi düzeyi arasında anlaml farklılı vardır.}

Katılımcıların muhasebe meslek tercihi ile ilgi düzeyine yönelik gerçekleştirilen analiz sonuçlarına Tablo 9'da yer verilmiştir. Buna göre 0,05 anlamlılık düzeyinde S18 ve S19 değişkenleri için anlamlı farklılık olduğu belirlenmiştir. Öğrencilerin muhasebe meslek mensubu olarak çalışmayı tercih etmesi ile TMS/TFRS'ye ilgi duyması ve konu ile ilgili açılacak dersleri seçmeleri arasında anlamlı farklılık olduğu söylenebilir. Diğer değişkenlerde ise $(\mathrm{P})>0,05$ bulunmuş ve $\mathrm{H}_{0}$ kabul edilmiştir. Öğrencilerin muhasebe mesleğini icra etmeyi istemesi ile diğer değişkenler arasında anlamlı ilişki bulunmadığı söylenebilir.

Tablo 9: Muhasebe Meslek Tercihi ile TMS/TFRS İlgi Düzeyine Yönelik Test Sonuçları

\begin{tabular}{|l|c|c|c|}
\hline \multicolumn{1}{|c|}{ Sorular } & Chi-Square & Df & Asymp. Sig. \\
\hline S7 & 5,622 & 2 &, 060 \\
\hline S8 & 4,712 & 2 &, 095 \\
\hline
\end{tabular}




\begin{tabular}{|l|c|c|c|}
\hline S9 & 1,500 & 2 &, 472 \\
\hline S13 & 1,838 & 2 &, 399 \\
\hline S18 & 19,116 & 2 &, 000 \\
\hline S19 & 34,270 & 2 &, 000 \\
\hline
\end{tabular}

$H_{5}=$ TMS/TFRS dersi alan öğrenciler ile almayan öğrencilerin TMS/TFRS ilgi düzeyi arasında anlamlı farklılık vardır.

Tablo 10'da TMS/TFRS ile ilgili ders alan öğrenciler ile almayan öğrencilerin TMS/TFRS ilgi düzeyine yönelik gerçekleştirilen analizlere yer verilmiştir. 0,05 anlamlılıkta $(\mathrm{P})<0,05$ bulunmuş $\mathrm{H}_{0}$ reddedilmiştir. Öğrencilerin TMS/TFRS ile ilgili ders alma durumu ile ilgi düzeyi arasında anlamlı fark olduğu tespit edilmiştir.

Tablo 10: Öğrencilerin TMS/TFRS'lerleİlgili Ders Alma Durumu İle TMS/TFRS İlgi Düzeyine Yönelik Test Sonuçları

\begin{tabular}{|l|c|c|c|c|}
\hline \multicolumn{1}{|c|}{ Sorular } & Mann-Whitney U & Wilcoxon W & Z & Asym. Sig. (2 tailed) \\
\hline S7 & 1122,500 & 11562,500 & $-6,325$ &, 000 \\
\hline S8 & 1633,500 & 12073,500 & $-4,543$ &, 000 \\
\hline S9 & 617,500 & 11057,500 & $-7,999$ &, 000 \\
\hline S13 & 1215,500 & 11655,500 & $-5,940$ &, 000 \\
\hline S18 & 1890,500 & 12330,500 & $-3,629$ &, 000 \\
\hline S19 & 1971,000 & 12411,000 & $-3,383$ &, 001 \\
\hline
\end{tabular}

$H_{6}=\ddot{O} \breve{g r e n c i l e r i n}$ TMS/TFRS ile ilgili derslerin zorunlu olarak verilmesini isteme durumu ile TMS/TFRS ilgi düzeyi arasında anlamlı farklılık vardır.

Dersin zorunlu olarak verilmesini isteyen öğrenciler ile istemeyenlerin TMS/TFRS ilgi düzeyinin tespitine yönelik gerçekleştirilen Mann- Whitney U testi sonucunda S8, S9, S13, S18 ve S19 değişkenlerinde 0,05 anlamlılıkta $(\mathrm{P})<0,05$ olduğundan anlamlı bir farklılık olduğu tespit edilirken $\mathrm{S} 7$ değişkeninde ise $(\mathrm{P})>0,05$ olduğundan anlamlı farklılık bulunamamıştır.

Tablo 11: TMS/TFRS'lerle İlgili Derslerin Zorunlu Olarak Verilmesini İsteyen Öğrenciler ile İstemeyen Öğrencilerin TMS/TFRS İlgi Düzeyi Test Sonuçları

\begin{tabular}{|l|c|c|c|c|}
\hline \multicolumn{1}{|c|}{ Sorular } & Mann-Whitney U & Wilcoxon W & Z & Asym. Sig. (2 tailed) \\
\hline S7 & 3572,500 & 6812,500 & $-1,819$ &, 069 \\
\hline S8 & 3400,000 & 6640,000 & $-2,311$ &, 021 \\
\hline S9 & 3187,500 & 6427,500 & $-2,908$ &, 004 \\
\hline S13 & 2744,500 & 5984,500 & $-4,174$ &, 000 \\
\hline S18 & 2565,500 & 5805,500 & $-4,685$ &, 000 \\
\hline S19 & 2118,000 & 5358,000 & $-6,018$ &, 000 \\
\hline
\end{tabular}

\subsubsection{Katılımcıların TMS/TFRS Hakkındaki Beklentilerine Yönelik Analizler}

Araştırmanın bu bölümünde öğrencilerin TMS/TFRS ders içeriğine yönelik beklentilerine ilişkin analizler gerçekleştirilmiştir. Bu kapsamda öğrencilerin TMS/TFRS üzerine ders alıp almadığı, TMS/TFRS öğrenmede hangi yöntemlerin katkı sağlayacağı ve TMS/TFRS'ye yönelik derslerde ne gibi değişiklikler yapılmasının fayda sağlayacağını belirlemeye yönelik analizler yer almaktadır. Tablo 12 incelendiğinde öğrencilerin 
\%77,8'i TMS/TFRS üzerine ders almadığını belirtirken \% 56,8'sı bölümde TMS/TFRS ile ilgili derslere zorunlu olarak yer verilmesini istemiştir. Ayrıca dersin sevdirilmesi ve uygulamaya yönelik ders işlenmesinin başarıyı olumlu yönde etkileyeceği ve TMS/TFRS ile ilgili seminerler, sertifika programları düzenlenmesinin de yararlı olacağı belirtilmiştir.

Tablo 12: TMS/TFRS'ye Yönelik Derslerden Beklentilerine İliş̧kin Verilen Cevapların Dağılımı

\begin{tabular}{|c|c|c|c|}
\hline & & Frekans & Yüzde \\
\hline \multirow{3}{*}{$\begin{array}{l}\text { TMS/TFRS üzerine aldığınız } \\
\text { ders var mı? }\end{array}$} & Evet & 41 & 22,2 \\
\hline & Hayır & 144 & 77,8 \\
\hline & Toplam & 185 & 100,0 \\
\hline \multirow{3}{*}{$\begin{array}{l}\text { TMS/TFRS ile ilgili zorunlu ders } \\
\text { verilmesini ister misiniz? }\end{array}$} & Evet & 105 & 56,8 \\
\hline & Hayır & 80 & 43,2 \\
\hline & Toplam & 185 & 100,0 \\
\hline \multirow{4}{*}{$\begin{array}{l}\text { TMS/TFRS'ye yönelik derslerde } \\
\text { ne gibi değişiklik olması fayda } \\
\text { sağlar? }\end{array}$} & $\begin{array}{l}\text { TMS/TFRS ayrı bir ders olarak } \\
\text { verilmeli }\end{array}$ & 61 & 33,0 \\
\hline & $\begin{array}{l}\text { TMS/TFRS konusu muhasebe } \\
\text { derslerinde daha çok yer almalı }\end{array}$ & 54 & 29,2 \\
\hline & $\begin{array}{c}\text { Sertifika programları ve seminerler } \\
\text { yapilmalı }\end{array}$ & 70 & 37,8 \\
\hline & Toplam & 185 & 100,0 \\
\hline \multirow{4}{*}{$\begin{array}{l}\text { TMS/TFRS öğrenmede “....” } \\
\text { yöntemi katk1 sağlar }\end{array}$} & Bir ders ortamında anlatılması & 74 & 40,0 \\
\hline & $\begin{array}{l}\text { TMS/TFRS uygulayan işletme } \\
\text { kayıtlarının incelenmesi }\end{array}$ & 38 & 20,5 \\
\hline & $\begin{array}{c}\text { Uzman kişiler tarafindan verilen } \\
\text { seminerlere katılma }\end{array}$ & 73 & 39,5 \\
\hline & Toplam & 185 & 100,0 \\
\hline \multirow{6}{*}{$\begin{array}{l}\text { Dersin uygulamaya yönelik } \\
\text { anlatılması ve sevdirilmesi } \\
\text { başarımı pozitif etkiler. }\end{array}$} & Kesinlikle Katıliyorum & 57 & 30,8 \\
\hline & Katıliyorum & 71 & 38,4 \\
\hline & Kararsızım & 37 & 20,0 \\
\hline & Katılmıyorum & 13 & 7,0 \\
\hline & Kesinlikle Katılmıyorum & 7 & 3,8 \\
\hline & Toplam & 185 & 100,0 \\
\hline \multirow{6}{*}{$\begin{array}{l}\text { TMS/TFRS konusundaki dersler } \\
\text { bölümde kesinlikle yer almalıdır. }\end{array}$} & Kesinlikle Katıliyorum & 26 & 14,1 \\
\hline & Katıliyorum & 94 & 50,8 \\
\hline & Kararsızım & 50 & 27,0 \\
\hline & Kat1lmiyorum & 12 & 6,5 \\
\hline & Kesinlikle Katılmıyorum & 3 & 1,6 \\
\hline & Toplam & 185 & 100,0 \\
\hline
\end{tabular}

Tablo 13 öğrencilerin TMS/TFRS ile ilgili ders almanın sağlayacağı yararlara ilişkin beklentilerini tespit etmek amacıyla oluşturulmuştur. Bu kapsamda öğrencilerin \%48,6'sı TMS/TFRS ile ilgili bilgi sahibi olmanın iş hayatında fayda sağlayacağını belirtmiştir. 
Tablo 13: TMS/TFRS ile İlgili Ders Almanın Sağlayacağı Yararlara Yönelik Beklentiler

\begin{tabular}{|l|c|c|}
\hline & Frekans & Yüzde \\
\hline İs için gireceğim sınavlarda yarar sağlar. & 37 & 20,0 \\
\hline Muhasebe bilgimi günceller. & 58 & 31,4 \\
\hline Gelecekte işimde yarar sağlar. & 90 & 48,6 \\
\hline \multicolumn{1}{|c|}{ Toplam } & $\mathbf{1 8 5}$ & $\mathbf{1 0 0 , 0}$ \\
\hline
\end{tabular}

\subsubsection{Katılımcıların TMS/TFRS Konusundaki Farkındalıklarına Yönelik Analizler}

Araştırmanın bu kısmında TMS/TFRS hakkındaki farkındalığı belirlemeye yönelik hipotezler, analiz sonuçları ve yorumlara yer verilmiştir.

$H_{I}=$ Öğrencilerin dâhil olduğu öğretim programı ile TMS/TFRS hakkındaki farkındalıkları arasında anlamlı farklılık vardır.

Katılımcıların dahil olduğu öğretim programı ile TMS/TFRS farkındalığı arası anlamlı fark olup olmadığı Mann-Whitney U testi ile analiz edilmiş ve analiz sonuçları Tablo 15 'te verilmiştir. Analiz sonucunda $(\mathrm{P})>$ 0,05 bulunmuş ve $\mathrm{H}_{0}$ kabul edilmiştir. Bu durumda birinci ve ikinci öğretim öğrencileri arası 0,05 anlamlılık düzeyinde TMS/TFRS ile ilgili farkındalıklarında istatiksel olarak anlamlı bir farklılığın olmadığı tespit edilmiştir.

Tablo 15: Öğretim Programları ile TMS/TFRS Farkındalık Arasındaki Farkı Belirlemeye Yönelik Test Sonuçları

\begin{tabular}{|l|c|c|c|c|}
\hline \multicolumn{1}{|c|}{ Sorular } & Mann-Whitney U & Wilcoxon W & Z & Asymp. Sig. (2- tailed) \\
\hline S2 & 4243,000 & 8248,000 &,- 093 &, 926 \\
\hline S3 & 4036,000 & 8041,000 &,- 705 &, 481 \\
\hline S4 & 4197,000 & 8202,000 &,- 224 &, 822 \\
\hline S5 & 4125,000 & 8781,000 &,- 466 &, 641 \\
\hline S6 & 4246,500 & 8251,500 &,- 076 &, 940 \\
\hline S10 & 4111,000 & 8116,000 &,- 485 &, 628 \\
\hline S11 & 3962,000 & 7967,000 &,- 917 &, 359 \\
\hline S12 & 4125,000 & 8130,000 &,- 449 &, 653 \\
\hline S14 & 4131,500 & 8136,500 &,- 399 &, 690 \\
\hline S15 & 4054,500 & 8059,500 &,- 669 &, 504 \\
\hline S16 & 3918,000 & 7923,000 & $-, 1,101$ &, 271 \\
\hline S17 & 3999,000 & 8004,000 &,- 819 &, 413 \\
\hline
\end{tabular}

$\mathrm{H}_{2}=\ddot{O} \breve{g r e n c i l e r i n}$ cinsiyetleri ile TMS/TFRS hakkındaki farkındalıkları arasında anlamlı farklılı vardır.

Tablo 16' da öğrencilerin cinsiyeti ile TMS/TFRS farkındalığına yönelik analiz sonuçlarına yer verilmiştir. Analiz sonucunda $(\mathrm{p})>0,05$ bulunduğundan $\mathrm{H}_{0}$ kabul edilmiştir. Bu kapsamda 0,05 anlamlılık düzeyinde öğrencilerin cinsiyetleri ile TMS/TFRS farkındalıkları arasında farklılığın anlamlı düzeyde olmadığı söylenebilir.

Tablo 16: Cinsiyet ile TMS/TFRS Hakkındaki Farkındalık Düzeyi Arasındaki Farkın Tespitine Yönelik Test Sonuçları 


\begin{tabular}{|l|c|c|c|c|}
\hline \multicolumn{1}{|c|}{ Sorular } & Mann-Whitney U & Wilcoxon W & Z & Asymp. Sig. (2- tailed) \\
\hline S2 & 3713,000 & 7629,000 & $-1,775$ &, 076 \\
\hline S3 & 4137,000 & 8053,000 &,- 392 &, 695 \\
\hline S4 & 4245,000 & 8161,000 &,- 069 &, 945 \\
\hline S5 & 4056,000 & 7972,000 &,- 672 &, 501 \\
\hline S6 & 4131,500 & 8047,500 &,- 405 &, 685 \\
\hline S10 & 4155,500 & 8071,500 &,- 339 &, 735 \\
\hline S11 & 4088,500 & 8841,500 &,- 531 &, 595 \\
\hline S12 & 4060,000 & 7976,000 &,- 363 &, 525 \\
\hline S14 & 4246,000 & 8162,000 &,- 062 &, 950 \\
\hline S15 & 3807,000 & 7723,000 & $-1,418$ &, 156 \\
\hline S16 & 4053,000 & 7969,000 &,- 669 &, 504 \\
\hline S17 & 4166,000 & 8082,000 &,- 306 &, 760 \\
\hline
\end{tabular}

$\mathrm{H}_{3}=$ Katılımcıların muhasebe ilgi düzeyi ile TMS/TFRS farkındalıkları arasında anlamlı farklılık vardır.

Katılımcıların muhasebe ilgi düzeyi ile farkındalıklarına yönelik test sonuçlarını içeren Tablo 17 incelendiğinde 0,05 anlamlılık düzeyinde S10, S15, S16 ve S17 değişkenlerinde istatiksel olarak anlamlı bir farklılığın bulunmadığı tespit edilmiştir. Diğer değişkenlerde ise $(\mathrm{P})<0,05$ olduğundan $\mathrm{H}_{1}$ hipotezi kabul edilmiş muhasebe ilgi düzeyi ile farkındalık düzeyi arasında farklılığın anlamlı düzeyde olduğu belirlenmiştir.

Tablo 17: Muhasebe İlgi Düzeyi ile TMS/TFRS Farkındalık Düzeyi Arasındaki Farkın Tespitine Yönelik Test Sonuçları

\begin{tabular}{|l|c|c|c|}
\hline \multicolumn{1}{|c|}{ Sorular } & Chi-Square & Df & Asymp. Sig. \\
\hline S2 & 11,021 & 4 &, 026 \\
\hline S3 & 23,472 & 4 &, 000 \\
\hline S4 & 13,225 & 4 &, 010 \\
\hline S5 & 9,799 & 4 &, 044 \\
\hline S6 & 20,771 & 4 &, 000 \\
\hline S10 & 7,623 & 4 &, 106 \\
\hline S11 & 10,450 & 4 &, 033 \\
\hline S12 & 11,025 & 4 &, 026 \\
\hline S14 & 10,167 & 4 &, 038 \\
\hline S15 & 7,330 & 4 &, 119 \\
\hline S16 & 4,292 & 4 &, 368 \\
\hline S17 & 5,533 & 4 &, 237 \\
\hline
\end{tabular}

\section{$\mathrm{H}_{4}=$ Meslek seçimi ile TMS/TFRS farkındalı̆̆ arasında anlamlı farklılık vardır.}

Katılımcıların meslek seçimi ile farkındalık düzeyi arasında anlamlı farklılık olup olmadığını belirlemeye yönelik gerçekleştirilen Kruskal-Wallis test sonuçlarını içeren Tablo 18 incelendiğinde S3 değişkeninde $(\mathrm{P})<$ 0,05 olduğundan istatiksel olarak anlamlı bir farklılık olduğu tespit edilmiştir. Diğer değişkenlerde ise 0,05 anlamlılık düzeyinde $\mathrm{H}_{1}$ hipotezi reddedilmiş, meslek seçimi ile öğrencilerin TMS/TFRS farkındalığı arasında anlamlı farklılık olmadığı belirlenmiştir. 
Tablo 18: Katılımcıların Meslek Seçimi ile TMS/TFRS Farkındalık Düzeyi Arasındaki Farkın Tespitine Yönelik Sonuçlar

\begin{tabular}{|l|c|c|c|}
\hline \multicolumn{1}{|c|}{ Sorular } & Chi-Square & Df & Asymp. Sig. \\
\hline S2 & 2,355 & 2 &, 308 \\
\hline S3 & 6,408 & 2 &, 041 \\
\hline S4 & 3,105 & 2 &, 212 \\
\hline S5 & 0,420 & 2 &, 811 \\
\hline S6 & 3,357 & 2 &, 187 \\
\hline S10 & 4,308 & 2 &, 116 \\
\hline S11 & 1,919 & 2 &, 383 \\
\hline S12 & 3,065 & 2 &, 216 \\
\hline S14 & 3,995 & 2 &, 136 \\
\hline S15 & 3,384 & 2 &, 184 \\
\hline S16 & 4,006 & 2 &, 135 \\
\hline S17 & 2,927 & 2 &, 231 \\
\hline
\end{tabular}

$H_{5}=$ TMS/TFRS ile ilgili ders alan öğrenciler ile almayan öğrencilerin TMS/TFRS farkındalı̆ğ arasında anlamlı farklılık vardır.

Öğrencilerin TMS/TFRS ile ilgili ders alma durumu ile TMS/TFRS farkındalıklarına ilişkin test sonuçları Tablo 19'da verilmiştir. S5 ve S17 değişkenlerinde TMS/TFRS ile ilgili ders alan ve almayan öğrenciler arasında 0,05 anlamlılık düzeyinde $\mathrm{H}_{0}$ hipotezi kabul edilerek anlamlı bir farklılığın olmadığ tespit edilirken diğer değişkenlerde $(\mathrm{P})<0,05$ bulunmuş $\mathrm{H}_{0}$ kabul edilmiştir. Bu kapsamda TMS/TFRS ile ilgili ders alan ve almayan öğrenciler arasında TMS/TFRS'lerin mesleki açıdan önemli olduğu, derste kullanılan materyallerin verimliliği etkilediği, TMS/TFRS'lerin ortak bir muhasebe dillinin ifadesi olduğu ve finansal tabloların oluşturulmasında tekdüzelik sağladığı konularında anlamlı farklılık olduğu tespit edilmiştir.

Tablo 19: Öğrencilerin TMS/TFRS İle İlgili Ders Alma Durumu İle TMS/TFRS Farkındalı̆̆ı Test Sonuçları

\begin{tabular}{|l|c|c|c|c|}
\hline \multicolumn{1}{|c|}{ Sorular } & Mann-Whitney U & Wilcoxon W & Z & Asymp. Sig. (2- tailed) \\
\hline S2 & 2035,500 & 12475,500 & $-3,525$ &, 000 \\
\hline S3 & 2123,000 & 12563,000 & $-2,980$ &, 003 \\
\hline S4 & 2398,000 & 12838,000 & $-1,994$ &, 046 \\
\hline S5 & 2607,000 & 13047,000 & $-1,315$ &, 188 \\
\hline S6 & 2176,500 & 12616,500 & $-2,769$ &, 006 \\
\hline S10 & 1321,000 & 11761,000 & $-5,908$ &, 000 \\
\hline S11 & 1952,000 & 12392,000 & $-3,559$ &, 000 \\
\hline S12 & 2228,500 & 12668,500 & $-2,659$ &, 008 \\
\hline S14 & 1187,000 & 11627,000 & $-6,029$ &, 000 \\
\hline S15 & 2420,000 & 12860,000 & $-1,968$ &, 049 \\
\hline S16 & 2258,500 & 12698,500 & $-2,595$ &, 009 \\
\hline S17 & 2417,500 & 12857,500 & $-1,929$ &, 054 \\
\hline
\end{tabular}

$H_{6}=$ TMS/TFRS ile ilgili derslerinin zorunlu olmasını isteyen öğrenciler ile istemeyen öğrencilerin TMS/TFRS farkındalı̆̆ arasında anlamlı farklılık vardır. 
Dersin zorunlu olmasını isteyen öğrenciler ile istemeyenler arasında TMS/TFRS farkındalığına yönelik analiz sonuçları incelendiğinde S5, S15, S16, S17 değişkenlerinde $(\mathrm{P})>0,05$ olduğundan $\mathrm{H}_{0}$ kabul edilmiştir. Diğer değişkenlerde ise TMS/TFRS derslerinin zorunlu olark verilmesini isteyen ve istemeyen öğrenciler arasında TMS/TFRS farkındalığı konusunda 0,05 anlamlılık düzeyinde istatiksel olarak anlamlı farklılıklar olduğu söylenebilir.

Tablo 20: Zorunlu TMS/TFRS Dersi İsteme Durumu İle TMS/TFRS Farkındalığına Yönelik Test Sonuçları

\begin{tabular}{|l|c|c|c|c|}
\hline \multicolumn{1}{|c|}{ Sorular } & Mann-Whitney U & Wilcoxon W & $\mathbf{Z}$ & $\begin{array}{c}\text { Asymp. Sig. (2- } \\
\text { tailed) }\end{array}$ \\
\hline S2 & 2625,500 & 5865,500 & $-5,078$ &, 000 \\
\hline S3 & 2103,500 & 5343,500 & $-6,318$ &, 000 \\
\hline S4 & 2858,500 & 6098,500 & $-4,048$ &, 000 \\
\hline S5 & 3588,000 & 6828,000 & $-1,956$ &, 050 \\
\hline S6 & 3333,500 & 6573,500 & $-2,594$ &, 009 \\
\hline S10 & 3174,500 & 6414,500 & $-3,114$ &, 002 \\
\hline S11 & 2798,500 & 6038,500 & $-4,182$ &, 000 \\
\hline S12 & 3275,500 & 6515,500 & $-2,848$ &, 004 \\
\hline S14 & 3170,000 & 6410,000 & $-2,950$ &, 003 \\
\hline S15 & 3654,500 & 6894,500 & $-1,692$ &, 091 \\
\hline S16 & 3517,000 & 6757,000 & $-2,142$ &, 032 \\
\hline S17 & 3665,000 & 6905,000 & $-1,619$ &, 106 \\
\hline
\end{tabular}

\section{SONUÇ}

Dünya ekonomisinde küreselleşme sürecinin etkisiyle uluslararası ticari ilişkiler artış göstermiş ve işletmeler farklı ülkelerde yatırım yapmaya başlamıştır. İşletmelerin kendi ülkeleri ile yatırım yaptığı ülkelerdeki muhasebe uygulamalarının farklılık göstermesi yatırımcılar açısından çeşitli zorluklar ortaya çıkartmış ve bu durum muhasebe alanında ortak bir dil oluşturma ihtiyacını da beraberinde getirmiştir.

Küresel çapta muhasebe uygulamalarında standartlaşmayı sağlamak adına UMS/UFRS'ler oluşturulmuş ve ülkelerin muhasebe uygulamalarını bu standartlarla uyumlu hale getirmesi amaçlanmıştır. Türkiye'de UMS/ UFRS'lerin birebir Türkçeye çevrilmesiyle TMS/TFRS'ler oluşturulmuş ve süreç TTK ile desteklenmiştir. Günümüzde uluslararası muhasebe ve finansal raporlama standartlarına ilişkin çalışmalar KGK tarafından yürütülmekte olup KGK işletmelerin uygulanması gereken finansal raporlama çerçevelerini belirlemektedir. Bu kapsamda birer meslek mensubu adayı olan üniversite öğrencilerinin TMS/TFRS'leri uygulayabilecek düzeyde eğitim alması son derece önem kazanmaktadır. Dolayısıyla üniversitelerde muhasebe eğitimi önlisans, lisans ve yüksek lisans düzeyinde verilmekte ve öğrenciler finansal raporlama çerçeveleri ile ilgili bilinçlendirilmeye çalışılmaktadır.

Bu bağlamda araştırmada Giresun Üniversitesi İktisadi ve İdari Bilimler Fakültesi İşletme Bölümü 3. ve 4. sınıf öğrencilerinin TMS/TFRS hakkında ilgi düzeyi, beklentileri ve farkındalıklarını ortaya koymak amaçlanmıştır. $\mathrm{Bu}$ amaçla uygulanan anket sonuçlarına göre araştırmaya katılan öğrencilerin \% 72,9 ’u muhasebe alanına ilgi duyan öğrencilerden oluşmaktadır. Öğrencilerin \% 61,7'si TMS/TFRS kavramını muhasebe ile ilgili aldıkları derslerde dersin öğretim üyesinden duyduğunu belirtmiştir. Bu sonuç TMS/TFRS haricindeki muhasebe ile ilgili derslerde TMS/TFRS'lere değinildiğini göstermektedir. Ayrıca katılımcıların çoğunluğu bölümde TMS/TFRS ile ilgili derslerin zorunlu olarak verilmesini arzu etmekte, bu durum öğrencilerin TMS/TFRS konusuna muhasebe derslerinde değinilmesi veya seçmeli ders olarak verilmesinden ziyade zorunlu ders olarak verilmesini istediklerini göstermektedir.

Öğrencilerin TMS/TFRS ilgi düzeyini ölçmek için yapılan analizlerde öğrencilerin cinsiyetleri ve öğretim türü ile TMS/TFRS ilgi düzeyi arası anlamlı farklılık bulunmazken muhasebe ilgi düzeyleri, muhasebe meslek 
seçimi, TMS/TFRS dersini alma durumu ve TMS/TFRS ile ilgili derslerin bölümde zorunlu olarak verilmesinin arzu edilmesi ile TMS/TFRS ilgi düzeyi arası anlamlı farklılıklar tespit edilmiştir. Bu sonuçlar konuya ilişkin literatürdeki çalışmalarla uyumludur.

Öğrencilerin TMS/TFRS farkındalık düzeylerinde cinsiyetleri ve öğretim türü bakımından anlamlı farklılık olmadığı belirlenmiştir. Her iki öğretim türünde muhasebeye yönelik derslerin içeriğinin benzer olması nedeniyle bu durum beklenen bir sonuç olup literatürdeki araştırma sonuçlarıyla uyum gösteren bir yapıda olduğu söylenebilir. Muhasebe ilgi düzeyi, muhasebe meslek seçimi, TMS/TFRS ile ilgili ders alma durumu ve dersin bölümde zorunlu olarak verilmesini arzu etmeleri ile TMS/TFRS farkındalık düzeyi arası anlamlı farklılık olduğu sonucuna ulaşılmıştır. Muhasebe ilgi düzeyi yüksek olan ve ileride muhasebe mesleğini icra etmeyi düşünen öğrencilerin TMS/TFRS farkındalık düzeyinin yüksek olması beklenen bir sonuç olup araştırma bu yönüyle Turhal ve Oğuz'un (2016) çalışmasında elde edilen sonuçlardan farklı özellik göstermektedir.

Öğrencilerin TMS/TFRS'ye yönelik beklentileri incelendiğinde çoğunluğun TMS/TFRS üzerine ayrı bir ders almadığı ve TMS/TFRS'lerin zorunlu ders olarak verilmesini istediği görülmektedir. Ayrıca TMS/TFRS'nin bir ders ortamında uygulamaya yönelik anlatılmasının, alanında uzman kişiler tarafından TMS/TFRS hakkında seminerler düzenlenmesinin başarıyı olumlu yönde etkileyeceği ve muhasebe meslek mensubu adayı olan üniversite öğrencilerinin TMS/TFRS hakkındaki ilgi düzeylerini ve farkındalıklarını arttıracağı söylenebilir. 


\section{KAYNAKÇA}

Akdoğan, Nalan (2007), “Türkiye Muhasebe / Finansal Raporlama Standartlarının Uygulanma Süreci: Sorunlar, Çözüm Önerileri”, Mali Çözüm Dergisi, S. 20: 102-117.

Altıntaş, A. Taylan (2011), "Uluslararası Muhasebe ve Türkiye'de Muhasebe Hukuku”, Sosyal Bilimler Dergisi, S. 1: 162-174

Atıgan, Fatma; Yükselen, Cemal (2018), "Marka Tutumu İle İmajının Marka Değeri ve Güveni Yaratılmasındaki Rolüyle, Tüketicinin Satın Alma Niyeti Üzerindeki Etkileri”, Beykent Üniversitesi Sosyal Bilimler Dergisi, C.11, S. 1: 35-53, doi: 10.18221/bujss.370614

Aysan, Mustafa A. (2008), "Uluslararası Finansal Raporlama Standartlarına Ulusal Uyum: Türkiye Örneği”, Muhasebe ve Finansman Dergisi, Ekim, S. 40: 44-53.

Aziz, Aysel (2017), Sosyal Bilimlerde Araştırma Yöntemleri ve Teknikleri, Ankara: Nobel Akademik Yayıncılık.

Çil Koçyiğit, Seyhan; Elitaş, Bilgi Leyli ve İşgüven, Mahmut Kadir (2016), "Lisans Öğrencilerinin TMS/TFRS Hakkındaki Farkındalıklarına Yönelik Bir Araştırma: Yalova Üniversitesi İktisadi ve İdari Bilimler Fakültesi Örneğì”, Uluslararası Alanya İşletme Fakültesi Dergisi, C. 8, S.1: 59-68.

Dalgar, Hüseyin; Çelik, İsmail ve Mortaş, Mustafa (2011), "Muhasebe Öğrenimi Gören Öğrencilerin TMS/TFRS Hakkındaki Farkındalıklarına Yönelik Bir Araştırma" Süleyman Demirel Üniversitesi İktisadi ve İdari Bilimler Fakültesi Dergisi, C.16, S.1: 217-230.

Demirkutlu Karakaya, Fatma (2014). "İşletme Lisans Öğrencilerinin Türkiye Muhasebe/Finansal Raporlama Standartları Hakkındaki İlgi Düzeyleri, Beklentileri ve Farkındalıkları: Gazi Üniversitesi İktisadi ve İdari Bilimler Fakültesi Örneği”, Gazi Üniversitesi İktisadi ve İdari Bilimler Fakültesi Dergisi, C. 16, S.2: 156-174

Erdoğan, Murat; Dinç, Engin (2009), "Türkiye Muhasebe Standartları ve Muhasebe Meslek Mensuplarının Bilgi Düzeylerinin İncelenmesi”, Muhasebe ve Finansman Dergisi, Temmuz S.43: 154-169.

Erol Fidan, Meral ve Uysal Taner (2017), "Türkiye Muhasebe ve Finansal Raporlama Standartları Konusunda Üniversite Öğrencilerinin Alg1 Düzeylerinin Ölçülmesi: Bilecik Şeyh Edebali Üniversitesi Örneği”, KMÜ Sosyal ve Ekonomik Araştırmalar Dergisi, C.19, S.33: 24-35

Gökçen, Gürbüz; Ataman, Başak; Cebeci, Yasin ve Cavlak, Hakan (2015), “Türkiye'deki Devlet Üniversitelerinin Lisans Programlarındaki Muhasebe Standartları Eğitimi Üzerine Bir Araştırma”, Marmara Üniversitesi Öneri Dergisi, C.11, S.44: 121-145 doi: 10.14783/od.v11i44. 5000080007

Gökçen, Gürbüz; Öztürk, Erkan ve Güleç, Ömer Faruk (2019), “ KÜMİ FRS Seti Taslağı, BOBİ FRS Seti ve Tam Set TMS/TFRS'nin Temel Konular Açısından Karşılaştırılması”, Finans Ekonomi ve Sosyal Araştırmalar Dergisi, C.4, S.3: 413-430 doi: 10.29106/fesa.61666

Kara, Suat; Tuna, Melek ve Hitay, Kezban (2016), "Üniversitelerde Uluslararası Muhasebe Standartları Eğitimi ve Balıkesir Üniversitesi'nde Bir Araştırma”, Uluslararası Alanya İşletme Fakültesi Dergisi, C.8, S.1: 159-174

Kıllı, Mustafa ve Küçüktüfekçi, Murat (2019), “Türkiye'deki Üniversitelerde TMS/TFRS Eğitimi Üzerine Bir Araştırma”, Erciyes Üniversitesi İktisadi ve İdari Bilimler Dergisi, S.51:39-66

Kocamaz, Hilal (2012), "Uluslararası Muhasebe Standartlarının Dünyada ve Türkiye'de Oluşum ve Gelişim Süreci”, Kahramanmaraş Sütçü İmam Üniversitesi İktisadi ve İdari Bilimler Fakültesi Dergisi, C.2, S.2: 105-120.

Koç Yalkın, Yüksel (2001), “Türkiye Muhasebe ve Denetim Standartları Kurulu’nun (TMUDESK) Çalışmaları ve Türkiye Muhasebe Standartları", Muhasebe ve Denetime Bakış Dergisi, Ekim, S.5: 1-14.

Kurnaz, Niyazi (2012), "Statistical Analysis of the Factors Affecting Accounting Students' Awareness of the TAS (Turkish Accounting Standards) and TFRS (Turkish Financial Reporting Standards)”, British Journal of Science, C. 4 , S.1: $142-156$

Kutlu, Hüseyin Ali (2010), "Muhasebe Eğitiminin, Nitelikli İşgücü Yetiştirme Açısından Değerlendirilmesi”, Muhasebe ve Finansman Dergisi, Nisan, S.46: 232-246.

Pekdemir, Recep (2003), Finansal Kiralama İşlemlerinde Değerleme ve Raporlama, Ankara: TÜRMOB Yayınları, Sirküler Rapor Serisi.

Sayar, Zafer (2002), “Oluşturulmakta Olan Türkiye Muhasebe Standartları Kurulu'nun Işığı Altında Türkiye'de Muhasebe Standartlarının Mevcut Durumu ve Kamuyu Aydınlatma”, Muhasebe ve Denetime Bakış Dergisi, Ekim, S.7: 73-80.

Sevilengül, Orhan (2009), Genel Muhasebe. Ankara: Gazi Kitabevi.

Şimşek, Kezban ve Şimşek, Orhan (2019), "Muhasebe Eğitimi Alan Lisans Öğrencilerinin TFRS (Türkiye Finansal Raporlama Standartları)/ TMS (Türkiye Muhasebe Standartları) Farkındalıklarının Belirlenmesine Yönelik Bir Araştırma”, Kastamonu Education Journal, C.27, S.6:2693-2700, Doi: 10.24106/kefdergi.3607

Turhan, Güllüzar; Oğuz, Mustafa (2016), “İşletme Lisans Öğrencilerinin Türkiye Muhasebe/Finansal Raporlama Standartları Hakkındaki İlgi Düzeyleri, Beklentileri ve Farkındalıkları: Balıkesir Üniversitesi İktisadi Ve İdari Bilimler Fakültesi Örneği”, Muhasebe Bilim Dünyası Dergisi, C.18, S.4: 881-917.

Üstündağ, Saim (2000), "Muhasebe Standartları Oluşturulması Süreci”, Muhasebe ve Denetime Bakış Dergisi, S.1: 31 57. 
Yanık, Ahmet; Yıldız, Ferhat (2013), "Lisans Ve Ön lisans Düzeyinde Öğrenim Gören Öğrencilerin Muhasebe Standartları Hakkındaki Algılarının Karşılaştırılması: Bir Araştırma”, Süleyman Demirel Üniversitesi İktisadi ve İdari Bilimler Fakültesi Dergisi, C.18, S.2: 443-458.

Yanık, Ahmet; Yıldız, Ferhat; Kara, Ekrem ve Günce, Nurcan (2013), "Muhasebe Eğitimi Gören Ön lisans Öğrencilerinin Muhasebe Standartları Hakkındaki Algıları Üzerine Bir Araştırma”, Dumlupınar Üniversitesi Sosyal Bilimler Dergisi, Nisan S.36: 243-252.

Yıldız, Ferhat; Yanık, Ahmet (2013), "Yükseköğretimde Öğrenim Gören Öğrencilerin Muhasebe ve Finansal Raporlama Standartları Hakkındaki Algıları: Ampirik Çalışma”, Süleyman Demirel Üniversitesi Sosyal Bilimler Enstitüsü Dergisi, C.1, S.17: 205-220.

Yılmaz, Baki (2007), "Muhasebe Standartlarının Oluşumu ve Uygulanma Alanı”, Sosyal Ekonomik Araştırmalar Dergisi, C.7, S.13: 139-153.

Yılmaz, Züleyha; Şahin, Zeynep ve Çankaya, Fikret (2014), “Orta Ve Doğu Karadeniz Bölgesindeki Öğrenci, Akademisyen Ve Uygulayıcıların TMS/TFRS Farkındalıkları ve Görüşleri Üzerine Bir Çalışma”, Muhasebe Bilim Dünyası Dergisi, C.16, S.2: 109-135.

Zaif, Figen; Ayanoğlu, Yıldız (2007), "Muhasebe Eğitiminde Kalitenin Arttırılmasında Ders Programlarının Önemi: Türkiye'de Bir İnceleme”, Gazi Üniversitesi İktisadi ve İdari Bilimler Fakültesi Dergisi, C:9, S.1: 115-136.

http://www.kgk.gov.tr/DynamicContentDetail/7890/TMS/TFRS-2019-Seti, (Erişim: 04.05.2019).

https://www.kgk.gov.tr/DynamicContentDetail/5151/Bu\%CC\%88yu\%CC\%88k-ve-Orta-Boy-

I\%CC\%87s\%CC\%A7letmeler-I\%CC\%87c\%CC\%A7in-Finansal-Raporlama-Standard\%C 4\%B1-

(BOBI\%CC\%87-FRS), (Erişim: 28.11.2019) 